\title{
E-LEARNING COURSE DESIGN IN TEACHER DESIGN TEAMS: Experiences in the Open University of Tanzania
}

\author{
Paper presented during the $13^{\text {th }}$ Biannual Conference for Research on Learning and \\ Instruction in Amsterdam, August 25 $5^{\text {th }}-29^{\text {th }}, 2009$. \\ Kassimu A. Nihuka \\ k.a.nihuka@gw.utwente.nl, \\ Open University of Tanzania, Dar es Salaam-Tanzania \\ $\&$ \\ Joke Voogt \\ j.m.voogt@gw.utwente.nl, \\ University of Twente, Enschede-The Netherlands
}

\begin{abstract}
Collaborative course design in teacher design teams (TDTs) has proved to be a promising professional development arrangement. This study explored the potential of TDTs in orienting teachers on course redesign for e-learning delivery at the context of Open University of Tanzania (OUT). Three teachers from the Institute of Continuing Education (ICE) at OUT worked in a design team and got supported on how to transform their traditional courses into e-learning courses. A sample of 67 Foundation course students from ICE was then invited to access the e-learning courses through offline Moodle Learning Management System (LMS) for a period of three months. Quantitative and qualitative data from teachers and students were collected. This contribution discusses experiences of teachers on collaborative course redesign and presents students experiences with the redesigned e-learning courses. Initial results show that both teachers were enthusiastic on working in the design team and students were satisfied with the e-learning courses. They encountered several challenges which require to be redressed accordingly. However, the findings show that despite its challenges, teacher design teams approach have enormous returns in terms of professional development of teachers and improvement of students support.
\end{abstract}

Keywords: E-learning, Teacher Design Teams, Collaboration and Distance Education

\section{INTRODUCTION}

Print media delivered to students through postal services or carried by teachers is the dominant approach for course delivery in distance education in most sub-Sahara African countries including Tanzania. Such an approach is often complemented with some regularly organized face-to-face sessions during which teachers meet students for some real time teaching and learning sessions. In the context of Open University of Tanzania, different challenges are reported (see for example OUT: ICT Policy, 2009; Mnyanyi \& Mbwette, 2009; Nihuka, 2009). These are: (i) inefficient interaction among students and between students and teachers, (ii) lack of effective communication and interaction between teachers and students (iii) delays in delivery of study materials and assignments, (iv) lack of immediate feedback on students' assignments and tests, (v) outdated reading resources and (vi) feelings of isolation.

Current literature reveal that Information and Communication Technologies (ICTs) have potential to redress most of these challenges (Hoven, 2000; Moore, 2003) and wide set of 
technologies are available to enhance learning in distance education. For the past half a decade now the Open University of Tanzania has done several efforts to integrate Moodle as a Learning Management System (Bakari, 2009). The efforts include (among) others the formulation of comprehensive institutional frameworks such as ICT Policy, ICT Master Plan and E-learning Implementation Strategy (OUT: ICT Policy, 2009; OUT: Master Plan, 2009; OUT: ICT Implementation Strategy, 2009).

According to the ICT policy, the university aims (among other things) to (i) transform paperbased course delivery to blended learning approach and (ii) train its teachers on e-learning courses development. Towards this end, professional development programs for teachers are important endeavors in the university. Several professional development programs for teachers have been conducted in the name of capacity building, workshop, seminar and training on e-learning to orient teachers on e-learning integration in education. Trend has shown that teachers deliver their courses in a traditional way because they have not transformed their courses into e-learning courses. This implies that probably such one time programs are ineffective in orienting teachers about course design, development and delivery. Different challenges are reported to confront e-learning integration efforts at the Open University of Tanzania (Bakari, 2008, 2009; Mbwette, 2009; OUT: ICT Policy, 2009; OUT: ICT Master Plan, 2009). The challenges are: (i) inadequacy of ICT infrastructures which affect teachers and students' access to technologies, (ii) ICT competence among some teachers and students, (iii) mindset and perceptions of some of the teachers, (iv) limited motivation among teachers, (v) power unreliability and (vi) narrow bandwidth which affect internet speed.

Since the transition to e-learning is a curriculum innovation, professional development for teachers is necessary in order to prepare them for the innovation (Penuel et al., 2007). According to Ball \& Cohen (1996), Deketelaere \& Kelchtermans (1996) and Mishra et al. (2007) the success of a curriculum innovation depends on the extent to which teachers are involved in the professional development through teacher design teams (TDTs). This study was designed to explore the impact of teacher design teams as a professional development arrangement on teachers' professional development and students support.

\section{TEACHER DESIGN TEAMS}

\section{Concept and potential}

Waddoups, Nancy and Earle (2004) provide a list of definitions of teacher design teams from the perspective of participants of such teams. They describe design teams as;

a cooperative group working together to produce a unit of instruction,

in a design team members are involved in creating a product, reshaping and synthesizing the product and in many ways creating a new fashion and

a collaborative group working together and building a community.

Central to these definitions is the idea of (i) working together, cooperation among members in designing; (ii) redesigning of courses or units of instruction or creating new fashion and (iii) building a community. These features allow teachers in the team to collaborate and support each other towards realizing a common goal. As such design teams have the potential to positively impact teachers' professional development (Penuel et al., 2007; Ball \& Cohen, 1996; Deketelaere \& Kelchtermans, 1996; Mishra et al., 2007).

Little (1997) distinguished four types of collegial collaborations which include; storytelling, helping each other, sharing of ideas and experiences, and joint working. Collaborations in design teams can also be fostered by (formal) presentations, interactions during training (and in design teams) and sharing of ideas about technology integration to colleagues (Waddoups 
et al., 2004). Teacher design teams can be organized into different sizes, for different tasks and with different kinds of supports (Mishra et al. 2007; Nieveen et al. 2007).

\section{Support for design teams on designing e-learning courses}

Teachers in the design teams require appropriate pedagogical and technical support for effective learning on how to integrate an innovation (Bates, 2000; Bianco et al. 2002; De Boer, 1999; Fisser, 2001; Lewis, 2002 cited in De Boer, 2004. This is because many teachers feel difficulties with transferring their courses from traditional into e-learning courses. Teachers require pedagogical support related to: first, designing of e-learning courses and development (Eyitayo \& Ginnini, 2004; Telnova, 2005). Experiences from TeleTop integration at Twente University shows that teachers needed support in planning to redesign their own courses (Bianco et al., 2002). Furthermore, teachers needed support in the actual redesigning process as well as the creation of their own TeleTop course environment. Support should be available for teachers at any stage of e-learning course design and development process (Eyitayo \& Ginnini, 2004). A well structured template with inbuilt instructional approach is quite effective in supporting teachers in course design (Telnova, 2005).

Second, teachers need pedagogical support related to designing of students' activities and instruction so that e-learning doesn't include just delivery of content (Eyitayo \& Ginnini, 2004; Telnova, 2005). Moreover, a one-to-one support for teachers engaging in e-learning activities, development and implementation and a continuous personal support / coaching to ensure a fearless familiarization with e-learning skills needed for e-learning are also necessary.

Additionally, technical support is also an important requirement for teachers to integrate elearning in education (Sife et al., 2007). Teachers need to be supported on activities like installation of computers and its accessories, installation of software, maintenance, network administration, and security management (Bakari et al., 2005; Fisser, 2001). In addition, teachers (and students) may need some basic skills related to troubleshooting to overcome common technical problems when using technologies. This is because in most of the developing countries including Tanzania there are very few technical experts to maintain ICTs (Bakari et al., 2005).

On the other hand students also require technical support related to e-learning strategies and how to use particular e-learning technology (Dzakiria, 2004; Fisser, 2001). Efforts towards elearning integration must therefore take into account the need to provide technical support to students during e-learning. According to Dzakaria (2004) students support is crucial in predicting students' motivation to use e-learning technologies. Student support in an elearning course can be offered by way of peer interaction during the course, from technical staff or course teacher (Concannon, Flynn \& Campbell, 2005). Where support is inadequate, students are likely to delay their completion of a program or drop out altogether (Khoo \& Idrus, 2004). In this respect, synchronous and asynchronous technologies may be quite useful to facilitate feedback, communication and interaction between teacher and students in a course (Cummings et al, 2002; Fahy, 2003; Hyman, 2002; Rovai, 2002; Tallent-Runnels, 2006; Tolmie \& Boyle, 2000).

\section{CONTEXT: Institute of Continuing Education}

This study involved teachers from the Institute of Continuing Education (ICE) at the Open University of Tanzania (OUT). ICE is the arm of the OUT that provides students with opportunities for continuing education. One of such opportunities is via a Foundation courses program (OFC). OFC offers a bridge that uplifts access to higher education for those who 
conventionally would be left out. Thus on successful completion, OFC prepares students for admission into OUT degree programs.

\section{Foundation courses}

There are 12 courses in the foundation courses (OFC) program. The following three courses were included in this study: Biology, Business studies and Economics and English language. These causes were included in the study because of the interest of respective teachers to participate in the study.

\section{Regional centers and Study materials}

Like students in other programs, students in the foundation courses are spread in 27 regional centers within Tanzania, a country of 0.95 million square kilometers. Of the 27 centers, only 7 centers have furnished computer laboratory with internet connectivity (Mbwette, 2009; Bakari, 2009). Traditionally, foundation course study materials (normally in prints) are distributed to the centers for students. Students collect study materials during registration on producing evidence that they have paid university fees.

\section{Challenges}

There are challenges associated with the delivery of foundation courses using printed materials. According to the OUT's Policy on Study Materials (on press), teachers and students encounter challenges of: outdated study materials, inadequate supply of materials, mismatch between size of the material to its credit rating, low quality of the materials and lack of study materials for some courses (e.g. Development studies in foundation courses).

Offline Moodle environment that embed some reading resources, assignments, course outlines and lectures as power point presentations was developed to blend delivery of foundation courses. The use of emails and mobile phones to facilitate communication and interaction between teachers and students was also considered important.

\section{PROFESSIONAL DEVELOPMENT SCENARIO}

Phases and timeframe of the intervention

The professional development intervention involved introductory workshops and working in a design team. To support the teachers on course redesign process, two workplace-based workshops (the first lasted for $3 \mathrm{hrs}$ and the second for $2 \mathrm{hrs}$ ) spread in a period of two months were conducted. Both workshops were based on a sound professional development model (Joyce \& Showers, 1995) and design guidelines generated from literature.

\section{Start workshop}

This aimed to discuss with teachers the theoretical underpinnings on e-learning and its potential in course delivery and students support. Its content was: (i) presentation and discussion of the theoretical rationale underlying e-learning integration, (ii) demonstration of Moodle-mediated e-learning course, (iii) identify part of the courses to be redesigned, (iv) discussion of the potential of collaboration in design teams in fostering skills in e-learning integration and $(\mathrm{v})$ decide on how frequent the teams should meet. At this stage the researcher's role was that of a facilitator. In addition, two other staffs that had background on e-learning were also invited as facilitators as well. 


\section{Course design in teacher design team}

After the start workshop teachers worked in a design team for a period of two months. A team of three teachers from Institute of Continuing Education (ICE) at the Open University of Tanzania (OUT) participated in the study. The design team aimed at providing teachers opportunity for collaborations and interactions towards e-learning course redesign. Again, design team provided an avenue for collegial discussions and support for each other.

The design team had the following characteristics: (i) comprised of 3 teachers, (ii) contained teachers from one institute (iii) each teacher worked on a particular foundation course, (iv) teachers' met regularly for discussion and supporting each other, (v) they re-examined course content and each one worked on his/her own course and (v) necessary support was provided to them. Teachers met once every week for an hour for a period of $2 \frac{1}{2}$ months in order to discuss and support each other on course redesigning process.

During the first design team meeting, teachers re-examined the content of their respective courses that required be redesigned and agreed each should design at least 5 lessons. They also worked out an action plan to guide course design tasks and developed a common template on how to organize the designed e-learning courses. Then, teachers collected or developed electronic copies of resources for their respective courses which could be attached into Moodle environment. The resources included: course outlines, assignments, study material, power point lectures, lecture notes and articles. In the subsequent design team meetings, teachers met to discuss mostly pedagogical issues (this is what brought them together as a design team) such as how to organize courses and resources in Moodle environment in accordance to the template, uploading of resources, availability of articles, scanning of some resources and importantly how to support students during the course.

During this stage the researcher was a participant observer and provided pedagogical support for teachers. There was also a technical staff that helped teachers on technical needs.

\section{Final workshop}

This was conducted after teachers had completed redesigning their courses in design team. The workshop aimed to share and discuss appropriate modalities to deliver e-learning courses. It also aimed to refine the redesigned courses and how to facilitate student learning. The content for the final workshop was: (i) presentations and discussion of the redesigned elearning courses, (ii) discussion of the appropriate modality to deliver courses and discussion on how to use email and mobile phones (to complement the current face-to-face and postal services communications), to provide immediate feedback to students, facilitate effective communication and interactions and ease delivery of course outlines, assignments and additional reading materials. Teachers spent a week to improve their courses before they were uploaded by technical staff into offline Moodle LMS installed in 25 PCs in one computer laboratory at the headquarters in Dar es Salaam and 10 PCs in another computer laboratory in Iringa center. For this stage the researcher remained as a facilitator and provided pedagogical clarifications and support. Technical staff helped on technical roles such as uploading of courses into Moodle platform.

\section{Implementation of e-learning courses}

A selected group of 67 Foundation course students, (i.e. 48 from Dar es Salaam and 19 from Iringa) were invited to access e-learning courses from computer laboratories in their regions. During this stage, teachers and the researcher worked together to orient students in Dar es Salaam and Iringa on how to access e-learning courses, how to navigate in Moodle environment during the course. Students were asked to communicate with teachers via emails and mobile phones whenever they required specific support from course teachers. The 
researcher liaised with the teachers and directors of the two regional centers to monitor students' use of Moolde courses and resources. Technical staff was involved for provision of technical support to students. Students accessed e-learning courses for a period of three consecutive months.

\section{METHODS}

Design of the pilot study

Design-based research was employed during the study. The pilot study aimed at (i) exploring the potential of teacher design teams for teachers professional development on e-learning integration in OUT's context and (ii) improvement of the intervention. According to Barab and Squire (2004), design research is a series of approaches, with the intent of producing new theories and practices that account for and potentially impact learning and teaching in naturalistic settings. The study investigated teachers' experiences with participation in design team and their perceptions of things they have learned from the team. It also sought to understand teacher support needed during e-learning course design and delivery, practices on course delivery and changes that have happened as a result of participation in design team. Students' experiences with e-learning course and delivery were also explored.

\section{Participants}

\section{Teachers}

A team of three teachers participated in the pilot study. Teachers first attended an introduction workshop and then worked in a design team where they were pedagogically and technically supported to transform their traditional courses into e-learning courses. Table 2 provides an overview of the background characteristics of the teachers, which shows that teachers in the design team had good knowledge and skills on computer applications and internet.

Table 2: Background characteristics of teachers

\begin{tabular}{|c|c|c|c|}
\hline \multirow[b]{2}{*}{ Characteristics } & \multicolumn{3}{|c|}{ Foundation course teachers } \\
\hline & $\begin{array}{l}\text { Biology } \\
\text { teacher }\end{array}$ & $\begin{array}{l}\text { Business studies and } \\
\text { economics teacher }\end{array}$ & $\begin{array}{l}\text { English } \\
\text { teacher }\end{array}$ \\
\hline & T1 & $\mathbf{T 2}$ & T3 \\
\hline gender & female & male & male \\
\hline age & 32 & 34 & 31 \\
\hline $\begin{array}{l}\text { years of experience at the } \\
\text { university } \\
\text { knowledge and skills on: }\end{array}$ & 1 & 3 & 1.5 \\
\hline (a) computer applications & good & good & good \\
\hline (b) internet & good & good & good \\
\hline
\end{tabular}

\section{Students}

67 foundation course students participated in the study. Table 3 provides background characteristics of students' base on students' questionnaires. Notice that students were drawn from Dar es Salaam and Iringa. In terms of computer competence, students in Dar es Salaam were average compared to colleagues in Iringa who were good. Students in the two regions recorded different frequencies of computer use. 
Table 3: Background characteristics of students

\begin{tabular}{|l|c|c|}
\hline & \multicolumn{2}{|c|}{ Regional centers } \\
\hline & Dar es salaam & Iringa \\
\hline gender & & 14 \\
\hline male & 19 & 05 \\
\hline female & 29 & $3.9(0.3)$ \\
\hline fremputer competence: X(SD) ${ }^{*}$ & $3.2(0.8)$ & $3.8(0.4)$ \\
\hline
\end{tabular}

Note: Scale: * $1=$ none, $2=$ poor, $3=$ average and $4=$ good

** 1=once per week, 2=at least 2-3 times per week, 3=at least 4-5 times per week and 4=everyday

\section{Instruments}

The following instruments which were developed for this study were used for data collection: questionnaires, interviews and researcher's log book.

\section{Teachers' questionnaire and interviews}

Questionnaire was administered to all three participating teachers at the end of introduction workshop, design phase and implementation phase to explore their initial experiences of working in design team. Based on the issues raised in the questionnaires, a total of three indepth interviews (one interview at each phase) were conducted with the teachers at the end of each phase. Using the questionnaires and interviews, data on teacher experiences of working in design team, support received and challenges encountered were collected. Teachers responses in interviews were audio taped, transcribed and major themes identified and clustered (Miles \& Huberman, 1994).

\section{Students' questionnaires and focus group interviews}

Questionnaires were administered to students after the implementation of the redesigned elearning courses. The questionnaires inquired students' perceptions and experiences with elearning courses. Four follow-up focus group interviews with students in Dar es Salaam and Iringa were conducted to investigate the experiences with e-learning courses more in-depth. Ease availability of students for the interviews was considered during selection. Data from questionnaires were analyzed using SPSS by computing descriptive statistics and results presented. Students responses in interviews were audio taped, transcribed and major themes identified and clustered (Miles \& Huberman, 1994).

\section{Researcher's logbook}

A logbook was kept by the researcher in order to document the process of working in the design team and on students' experiences on e-learning course. Information recorded in the logbook was analyzed qualitatively using data reduction technique. Recorded observations were scrutinized and major themes identified and clustered (Miles \& Huberman, 1994).

\section{RESULTS}

\section{Teachers experiences with professional development scenario}

\section{Workshop}

Overall, teachers found the workshop interesting; according to their expectations and that it was useful for their professional growth. They pointed out that the workshop enhanced their understanding of: (i) e-learning course development, (ii) course delivery using offline Moodle LMS and (iii) the use of emails and mobile phones for communication, interaction and provision of feedback to students. According to the teachers, the workshop had several 
strengths such as being focused, involvement of participants and fitted well into their daily schedules.

Furthermore, teachers identified the following aspects of the workshop as useful: organization of the workshop, relevance of handouts, presentations, discussions, demonstrations and group works. On the other hand, they identified several weaknesses for some aspects of the workshop, such as few demonstrations on how to use offline Moodle and on how to use mobile phone, and lack of incentive during the workshop.

Teachers expressed some concerns related to costs involved in using mobile phones to communicate with students. They realized that sending short messages was comparatively cheaper.

\section{Teacher design team}

Teachers' experiences with working in a design team were also investigated. Teachers expressed that they liked the idea of design team and that it was interesting working in the team. Specifically teachers liked collaborations, discussions, free conversations, advices and the supports offered in the design team. Moreover, teachers pointed out that they benefited from the collaborations and discussions in the design team especially in terms of enhancing their skills on course development for e-learning delivery and on how to support students. Teachers strongly agreed that the supports that were offered when working in design team were useful and increased their confidence in e-learning course design and managed to transform their courses into e-learning course.

Teachers in the design team expressed to encounter several challenges when working in the team as presented in Table 4. Overall, teachers found working in design team as demanding but appreciated its gains.

Table 4: Challenges of working in design team

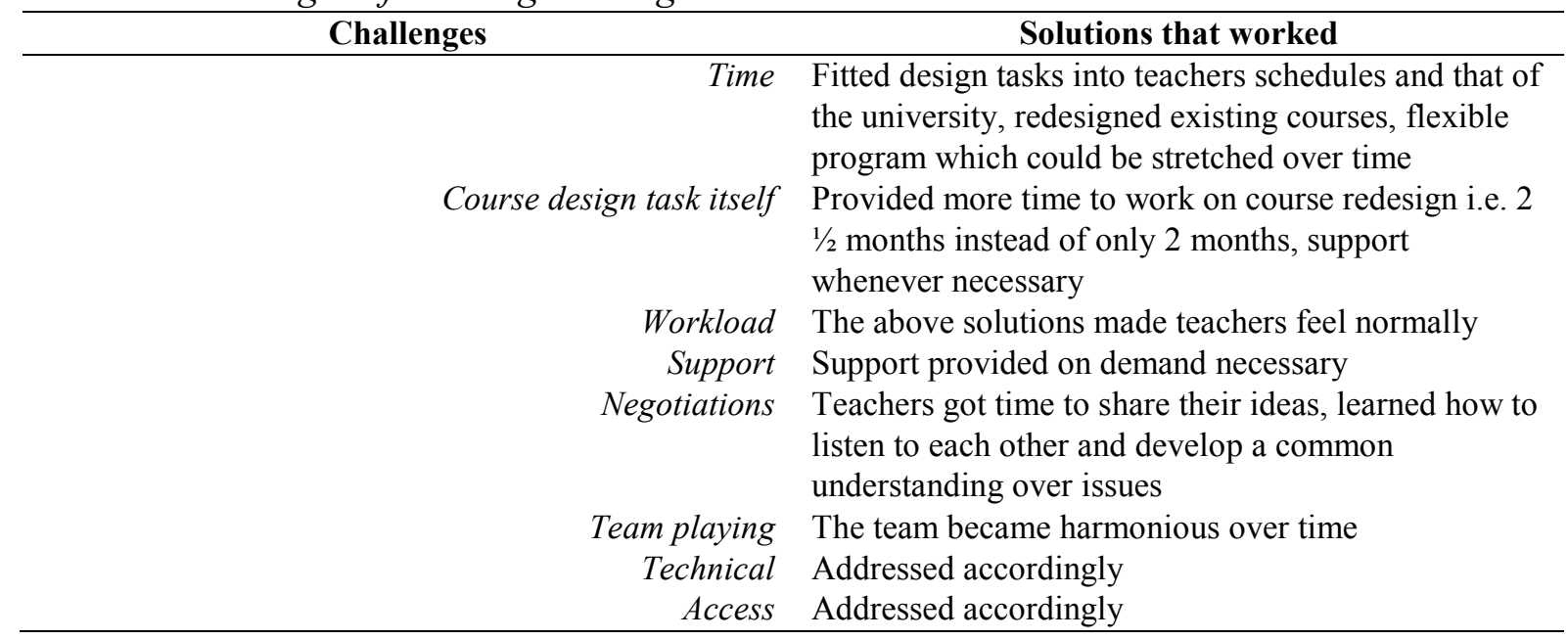

Notice in Table 4 that teachers considered the following as challenges: time, workload, course design task, support, negotiations and team playing, technical and access to technologies. Most of these challenges were attended accordingly as shown in the Table.

\section{Teacher learning in design team}

Teachers pointed out several specific things that they have learned as a result of participation in design team. In terms of professional skills, overall teachers expressed to have learned about course redesign and the use of offline Moodle. They also indicated that as a result of 
working in the design team, they have learned about how and when to use email and mobile phone technologies for communication, interaction and provision of feedback to students during e-learning course.

Teachers found the idea to use emails and mobile phones to support students during elearning course as interesting. However, they had different views regarding the usability of emails, mobile phones and postal services to support students. According to one of the teachers, mobile phone is expensive to maintain but found short messages as convenient. Generally, teachers liked emails more than mobile phones because they feel that emails are free to use although requires regular checking and reading of mails and reply them on time.

Teachers reported to have learned team working skills and tolerance. As a result of working in the design team, teachers learned tolerance to differing ideas, how to cope with colleague's different ideas on certain things, how to compromise and develop a common understanding and more importantly team working.

\section{Teacher support}

The kinds and usefulness of supports that teachers received/needed during course development in design teams and at delivery were also evaluated. Teachers felt they received support they needed during course development in design team although, according to them the support was available on demand. Particularly, teachers expressed that they appreciated pedagogical support on the following activities: how to use template to organize the redesigned courses, how to redesign courses, planning and on the actual process of course development and uploading of courses into offline Moodle LMS. They also expressed that they appreciated technical support related to activities such as: installation of Moodle software, uploading of power point lecturers into offline Moodle LMS, uploading of resources such lecture notes, course book, assignments and course outlines into Moodle LMS.

According to the teacher, they did not need pedagogical and technical support for activities such as: designing of students' activities, writing of instructions for the course, preparation of power point presentations and assembling of computer accessories. Additionally, teachers expressed that they required less support during e-learning delivery compared to course development stage. Mostly teachers needed support on how to send collective email replies to students.

Teachers provided different suggestions to improve provision of support in design team in future as presented in Table 5. According to the teachers, improvement of support will make teachers more effective and complete course development on time.

Table 5: Suggestions for improvement of support in design team

\section{Teachers suggestions}

- Identification of specific tasks for teachers to work on during course development

- Support on how to search articles

- Provision of sample structure on how to organize e-learning course

- There should be 2 technical staff per team

- Visit teachers at agreed intervals and regularly

- Need for plenary sessions for discussions about courses and how to improve them

- Teams must contain teachers teaching related courses so that they can help each other meaningfully

- More awareness sessions required

- Improved facilities for e-learning course development

- Institutional budget should consider e-learning enhancement 
Teachers encountered some pedagogical, technical and access-related challenges during course delivery as shown in Table 6a and 6b. Notice in Table 6a that for course delivery teachers had to encourage some students to access courses and were required to provide immediate feedback or replies to students.

Table 6a: Pedagogical challenges

\begin{tabular}{|c|c|}
\hline Challenges & Ways used to address the challenges \\
\hline $\begin{array}{l}\text { - Infrequent access of e-learning courses by } \\
\text { student } \\
\text { - } \quad \begin{array}{l}\text { Required to immediately reply or provide } \\
\text { feedbacks to students }\end{array}\end{array}$ & $\begin{array}{l}\text { - Initially had to structure meetings with } \\
\text { students at the centers for them to come and } \\
\text { experience courses. } \\
\text { - Made replies/feedback in mornings }\end{array}$ \\
\hline
\end{tabular}

Additionally, teachers encountered some technical and access challenges during course delivery as presented in Table 6b. They included: power fluctuations and cuts, slow internet speed, how to run course back up and course restoration, and email delivery failures. They also experienced some challenges related to costs involved in using mobile phones and reachability of some students.

Table 6b: Technical and Access challenges

\section{Challenges}

Technical

course back up

course restoration

mail delivery failure

Access

power cuts

power fluctuations

slow internet speed due to small bandwidth

mobile phones are expensive in terms of purchasing credit and when calling to

different service providers

some students were not reachable by mobile phone during the course

\section{Changed teacher practices}

The following teacher practices have changed: First, regarding course delivery, in addition to using traditional print-based course delivery approach, teachers in the study used offline Moodle LMS to deliver their courses. Teachers used emails and mobile phone (although to different extents) to complement the traditional postal services. Second, in terms of supporting students, teachers expressed that the following practices have changed to large extent: delivery of assignments and extra reading resources to students, use of emails and mobile phones to communicate and interact with students. According to the teachers, they used emails and mobile phones for communication and interaction with students and for responding to student's emails, questions and for feedback on students' tasks to a large extent.

Teachers in the study used emails first of all, followed by mobile phone to communicate with students. None of the teachers except one (who used postal service for about 1-2 times during the course to deliver assignment to students) indicated to have used postal services during the course. Moreover, none of the teachers in the study used emails for delivery of assignments, course outlines and extra reading resources during the course. Mobile phone was used only to a limited extent; in fact it was not used for delivery of assignments, course outlines and 
reading resources. According to the teachers, this is because mobile phones are expensive in terms of purchasing of credit, for calling to different service providers and un-reach-ability of some students during the course.

Another practice that also changed as a result of working in the design team is teachers' mind-set regarding support seeking tendency. As a result of working in design team, teachers expressed that they preferred going for a support from colleagues than working in isolation in office. Teachers associated all this changes not only to working in design teams but also to the support given when working in the design team.

\section{Students' experiences}

Students' experiences with the e-learning foundation courses and delivery were explored during the study and results are presented in Table 7.

\section{Table 7: Students experiences with e-learning courses and delivery}

\begin{tabular}{rcc} 
Experiences with e-learning courses & Mean \\
N=67 & (SD) \\
The course is generally interesting & 4.4 & 0.67 \\
The course is clear & 4.2 & 0.80 \\
Structure of the course is clear & 4.2 & 0.72 \\
Organization of the course is clear & 4.2 & 0.83 \\
Delivery of the course is well supported by emails & 4.3 & 0.76 \\
Delivery of the course is well supported by mobile phone & 3.9 & 0.73 \\
Easy to follow links and navigations in the moodle & 4.0 & 0.99 \\
Reading materials were relevant and useful & 4.2 & 1.0 \\
I liked using moodle LMS & 4.3 & 0.62 \\
Enjoyed using mobile phone during the course & 4.0 & 1.0 \\
He course allowed easy access to course outlines & 4.4 & 1.0 \\
He course allowed easy access to assignments & 4.5 & 1.4 \\
He course allowed easy access to reading resources & 4.6 & 0.73 \\
\hline
\end{tabular}

Note: Scale: $1=$ Strongly disagree, $2=$ Disagree, $3=$ Neutral, $4=$ Agree and $5=$ Strongly agree

Results in Table 7 show that generally the course was interesting as indicated by mean values higher than 3. Students liked the structure of the course and that its organization as clear (Mean 4.2, SD 0.72). The layout of the course was just appropriate (Mean 4.2, SD 0.83). The delivery approach of the e-learning course was well supported by emails (Mean 4.3, SD 0.73) and mobile phone (Mean 3.9, SD 0.99) technologies. It was easy to follow the links and navigations in the Moodle (Mean 4.0, SD 1.0).

Students liked the way they accessed resources from offline Moodle. E-learning course allowed easy access to course outlines (Mean 4.5, SD 0.73), assignments (Mean 4.5, SD 0.70) and extra reading resources (Mean 4.6, SD 0.68). Students found the reading resources as relevant and useful. For communication and interactions, results in Table 7 show that students enjoyed using emails (Mean 4.0, SD 1.0) and mobile phones (Mean 3.4, SD 1.4) to communicate and interact with teachers.

Table 8 presents frequencies of communication and interaction between students and teachers using different technologies during e-learning courses. 
Table 8: Frequency of communication and interaction with teachers

\begin{tabular}{|c|c|c|c|c|c|c|c|c|c|c|c|c|}
\hline \multirow[b]{2}{*}{$\begin{array}{r}\text { Reasons for communications } \\
\text { and interactions }\end{array}$} & \multicolumn{3}{|c|}{ Never } & \multicolumn{3}{|c|}{$\begin{array}{c}1-2 \text { times during the } \\
\text { course }\end{array}$} & \multicolumn{3}{|c|}{$\begin{array}{l}\text { 3-6 times during } \\
\text { the course }\end{array}$} & \multicolumn{3}{|c|}{$\begin{array}{c}7-10 \text { times during the } \\
\text { course }\end{array}$} \\
\hline & . & 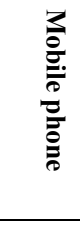 & 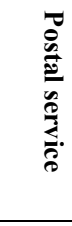 & . Th: & 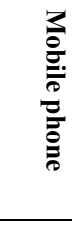 & 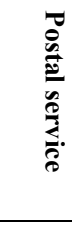 & 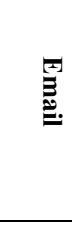 & 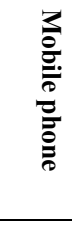 & 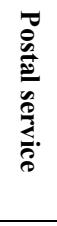 & 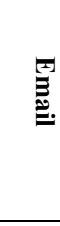 & 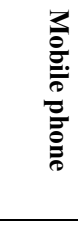 & 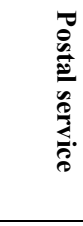 \\
\hline Assignments & 16.4 & 31.3 & 76.1 & 17.9 & 32.8 & 19.4 & 41.8 & 29.9 & 1.5 & 23.9 & 06 & 1.5 \\
\hline Course outlines & 17.9 & 47.8 & 91 & 31.3 & 20.9 & 4.5 & 23.9 & 17.9 & 1.5 & 23.9 & 13.4 & 1.5 \\
\hline $\begin{array}{r}\text { Ask for reading resources from } \\
\text { lecturers }\end{array}$ & 35.8 & 52.2 & 94 & 20.9 & 14.9 & 1.5 & 19.4 & 16.4 & 1.5 & 23.9 & 16.4 & 1.5 \\
\hline Clarification of concepts & 39.4 & 47.8 & 94 & 16.7 & 16.4 & 0 & 15.2 & 20.9 & 03 & 28.8 & 14.9 & 1.5 \\
\hline $\begin{array}{r}\text { Receiving feedback from } \\
\text { lecturers }\end{array}$ & 19.4 & 46.3 & 91 & 28.4 & 14.9 & 03 & 22.4 & 14.9 & 4.5 & 28.4 & 23.9 & 0 \\
\hline Responding to emails & 25.4 & 46.3 & 92.5 & 22.4 & 17.9 & 1.5 & 19.4 & 09 & 1.5 & 26.9 & 26.9 & 03 \\
\hline
\end{tabular}

Notice in Table 8 that only a few students used postal services during the course in favor of emails and mobile phones. For example it is clear in Table 8 that at least $42 \%$ of the students used emails for about 3-6 times during the course for sending assignments to lecturers. Again, over $31 \%$ of students in the study used emails for about 1-2 times during the course to communicate with lecturers on issues related to course outlines. In addition, $28 \%$ of students used emails to receive feedback from lecturers and $22 \%$ used emails to respond to emails from teachers during the course.

According to students, e-learning courses had several weaknesses such as: lack of power point presentations in some courses, lack of variety of reading resources, inflexibility of the e-learning course to location and time, lack of reliable printing and photocopying facilities during the course.

Like teachers, students also encountered several technical and access related challenges as presented in Table 10.

Table 10: Technical and access challenges encountered by students

\begin{tabular}{ll}
\hline Challenges \\
\hline Accessical & \\
& $\begin{array}{l}\text { uploading of attachments to emails } \\
\text { some basic trouble shootings } \\
\text { bouncing back of emails }\end{array}$ \\
& power cuts \\
& power fluctuations \\
& slow internet speed \\
& some lectures avoid emails \\
& expensive to use emails and mobile phones \\
& no access to printer and photocopy facilities during the course \\
& some teachers were not reachable by mobile phone \\
& lack of time to work on computers
\end{tabular}


From Table 10 students encountered the following technical problems during e-learning course: incompetency in uploading attachments to emails, lack of basic trouble shooting skills, and bouncing back of some emails. They also encountered challenges to access some e-leaning technologies as well. These included: power cuts, power fluctuations, slow internet speed, some lectures avoid emails, expensive to use emails and mobile phones, lack of access to printer and photocopy facilities during the course, some teachers were not reachable by mobile phones and lack of time to work on computers.

\section{CONCLUSION AND DISCUSSION}

The results of this study reveal that teacher design team arrangement that was used in this study seems promising in promoting teachers professional competences in transforming traditional print-based courses into e-learning courses. Both teachers were enthusiastic on working in the design team and students were satisfied with the e-learning courses. Teachers benefited from collaborations in the design team because they enhanced their skills on course redesign for e-learning delivery and on how to support students during e-learning course (Desimone et al., 2002; Garet et al., 1999; Jonathan \& Herbert, 2000; Mishra et al., 2007).

On the other hand, despite its enormous returns working in design team seems a challenging endeavor especially for distance education teachers who are involved in invigilation of examinations, conduct face-to-face sessions, and supervise field trainings and marking of piles of assignments, tests and examinations. Harmonizing tasks of the team to teachers' schedules and university almanac seemed a promising strategy during this study. It was not possible to influence the time that the teachers had available for their participation in the design tem as reported in another study by Voogt et al. (2005).

Initially teachers found difficulty to transform their courses from traditional to e-learning courses. As a result of provision of pedagogical and technical support for the teachers, they eventually managed to have e-learning versions of their courses. This finding is not peculiar to this study because is also reported in another study by De Boer (2004). In this study teachers required pedagogical support on how to design e-learning courses and development, planning on how to redesign their own courses how to carry out actual redesigning process as well as the creation of their own e-learning version courses. The biggest challenge however was to ensure that the appropriate support is available to the teachers whenever they required. Lack of enough technical staff in the university (Bakari et al., 2005) exacerbated the situation. However when guided properly, the only one technical staff seemed quite useful during the study. A long term solution may consider training some teachers and students on some basic skills related to troubleshooting.

As a result of professional development through teacher design team, teachers' practices in terms of course delivery practices seemed changed. Teachers used an offline Moodle LMS to complement traditional print-based mode. Additionally, teachers used emails and mobile phone to communicate and interact with students as was also suggested in a umber of other studies (Cummings et al., 2002; Fahy, 2003; Hyman, 2002; Rovai, 2002; Tallent-Runnels, 2006; Tolmie \& Boyle, 2000). According to Dzakaria (2004) adequate support for students is crucial in motivating them to use e-learning technologies. During this study, more than half of students appreciated the support received from teachers during e-learning courses (compared to print-based mode). Also the e-learning delivery approach seemed promising in addressing students' challenges such as: delays in delivery of assignments, course outlines, reading resources and lack of regular communications and interactions with teachers.

Several implications for professional development and students support can be inferred from results of this study. Regarding professional development attempt should be made to establish 
harmonious state between introduction workshop and activities of design team on one hand and schedules of teachers and the university almanac on the other. This will certainly contribute to more gains by teachers from professional development arrangement. Teachers (and students) must get opportunity to explore the importance of using short text messages as an alternative to making phone calls in mobile phones since the later was found to be expensive. There is also need for the technical staff to be readily available for teachers (and students) during e-learning courses. Importantly, regular visits to the teachers may be arranged to effectively support teachers in the process.

In terms of students support, first a thorough orientation on how to learn via e-learning environment should be considered for students. Despite competences on basic computer and internet applications, students must be acquitted with specific basic competences related to elearning such as when and how to use emails and mobile phones, how to download resources from offline Moodle, and when, for what purpose and how often to communicate with teachers during the course.

In general, teacher design team arrangement seemed promising in teachers at the context of Open University of Tanzania, a distance education university. In such an arrangement, introduction workshop and support for teachers on course design, development, delivery and students support have a significant role. Teachers learn and grow professionally on how to systematically integrate e-learning technologies to redress particular pedagogical challenges in their courses. However, working in design teams and e-learning integration in distance education and students support using new technologies is a challenging endeavour.

\section{REFERENCES}

Ball, D.L. \& Cohen, D.K. (1996). Reform by the book: What is - or might be - the role curriculum materials in teacher learning and instructional reform. Educational Researcher, 25(9), 6-8.

Bakari, J.K., Tarimo, C.N., Yngstrom, L. and Magnusson, C. (2005) "State of ICT security management in the institutions of higher learning in developing countries: Tanzania Case Study," Paper presented at the Fifth IEEE International Conference on Advanced Learning Technologies (ICALT'05). pp. 1007-1011.

Bakari, J. K (2009). ICT at OUT: Achievements, challenges and future prospects. Paper presented during Rolling strategic plan review at Golden Tulip Hotel, $17^{\text {th }}-18^{\text {th }}$, April, 2009, Dar es salaam-Tanzania.

Bates, A. W. (2000). Managing technological change: Strategies for college and university leaders. San Francisco: Jossey-Bass.

Barab, S and Squire, K. (2004). Design-based research: Putting a stake in the ground. The Journal of the Learning Sciences. 13(1), 1-14.

Bianco, M., Collis, B., Cooke, A., and Margaryan, A. (2002). Instructor support for new learning approaches involving technology. (Retrieved on $17^{\text {th }}$ October, 2008 from http://www.academy.gcal.ac.uk/anoush/fulltexts/SEDI_article_16-07-02.pdf)

Concannon, F., Flynn, A., \& Campbell, M. (2005). What campus-based students think about the quality and benefits of e-learning? British Journal of Educational Technology, 36(3), 501-512.

De Boer, W. (2004). Flexibility support for a changing university, Doctoral Thesis at University of Twente, Enschede.

Desimone, L. M., Porter, A. C., Garet, M. S., Yoon, K. S., and Birman, B. F. (2002). Effects of professional development on teachers'instruction: Results from three-year longitudinal study. Educational Evaluation and Policy, 24(2), 81-112

Deketelaere, A. \& Kelchtermans, G. (1996). Collaborative curriculum development: An encounter of different professional knowledge systems. Teachers and Teaching: Theory and Practice, 2(1), 71-85. 
Dzakiria, H. (2004). Technology does not always teach distance learners, but effective distance teachers do... Malaysian Online Journal of Instructional Technology, 1(1), 60-81

Fisser, P., and DeBoer, W. (1999). A decision support tool for web-supported course design. Journal of Computer Assisted Learning, 15(1999), 255-256

Fisser, P. (2001). Using ICT in higher education. A Process of change in higher education, Doctoral Thesis at University of Twente, Enschede.

Garet, M. S., Birman, B. F., Porter, A. C., Desimone, L., and Herman, R. (1999). Designing effective professional development: Lessons from the Eisenhower program (and) technical appendices. US department of education.

Jonathan A. S and Herbert M. T. (2000). The Effects of Professional Development on Science Teaching Practices and Classroom Culture. Journal of Research in Science Teaching, 37(9), 963980.

Joyce, B., and Showers, B. (1995). Student achievement through staff development: Fundamentals of school renewal (2nd ed.). White Plains, NY: Longman.

Mwette, T. S. A. (2009). A decade of delivery of open and distance education by the Open University of Tanzania in Africa and beyond. Paper presented in an International forum on "A decade of distance education in the commonwealth: Achievements and challenges", Abuja-Nigeria, $18^{\text {th }}$ $20^{\text {th }}$ May, 2009.

Miles, M. B and Huberman, A. M (1994). An Expanded Source book, Qualitative Data Analysis. $2^{\text {nd }}$ Edition. London, SAGE Publications.

Mishra, P., Koehler, M.J. \& Zhao, Y. (2007). Faculty Development by Design: Integrating Technology in Higher Education. Charlotte, NC: Information Age Publishing.

Moore, M.G. (2003). Preface. In M.G. Moore, \& W. Anderson (Eds.), Handbook of distance education. Hillsdale, NJ: Lawrence Erlbaum Associates, Inc.

Mnyanyi, C. B. F., and Mbwette, T. S. A. (2009). Open and distance learning in professional development in third world countries. Paper presented at Maastricht's 23rd International Conference on Distance Education, 2009. Retrieved on $25^{\text {th }}$ June, 2009 from: http://www.ou.nl/Docs/Campagnes/ICDE2009/Papers/Final_paper_296Cosmas.pdf.

Nieveen, N., Handelzalts, A., Van den Akker, J., and Homminga, S. (2005). Teacher design teams: A scenario for school-based curriculum innovation. Paper presented at the ECER 2005, Dublin, Ireland

Nihuka, K. (2008). The feasibility of e-learning integration in course delivery at the Open University of Tanzania. Master of educational science and technology thesis. University of Twente, Enschede - The Netherlands.

Open University of Tanzania (on press): Policy and operational procedures on study materials. Dar es salaam-Tanzania

Open University of Tanzania (2009): E-learning Implementation Strategy for 2009/10-2013/14. Dar es salaam-Tanzania.

Open University of Tanzania (2009): Information and communication technology (ICT) master plan for 2009/10-2013/14. Dar es salaam-Tanzania

Open University of Tanzania (2009). Information and communication technology (ICT) policy plan for 2009/10 - 2013/14. Dar es salaam, Tanzania

Parke, H. M., and Coble, C. R. (1997). Teachers designing curriculum as professional development: A model for transformative science teaching. Journal of Research in Science Teaching, 34(8), 773789

Penuel, W.R, Fishman, B.J., Yamaguchi, R., \& Gallagher, L.P. (2007). What makes professional development effective? Strategies that foster curriculum implementation. American Educational Research Journal, 44(4), 921-958.

Sife, A. S., Lwoga, E.T.,\& Sanga, C. (2007). New technologies for teaching and learning: Challenges for higher learning institutions in developing countries. International Journal of Education and Development using Information and Communication Technology,3(20), 57-67. 
Telnova, T. (2005). Development of template for learning objectives within the learning content management system eXact for Digitale Universiteit, Master Thesis at University of Twente, Enschede.

Voogt, J., Almekinders, M., Van den Akker, J. \& Moonen, B. (2005). A 'blended' in-service arrangement for classroom technology integration: impacts on teachers and students. Computers in Human Behavior, 21, 523-539.

Waddoups, G. L., Wentworth. N., and Earle, R. (2004). Principles of technology integration and curriculum development: A faculty design team approach. (Retrieved on $15^{\text {th }}$ October, 2008). 